chronic diarrhoea and malnutrition. Arch Dis Child 1990;65:189-91.

2 Hill ID, Sinclair-Smith C, Lastovica AJ, et al. Transient protein losing enteropathy associated with acute gastritis and Campylobacter pylori. Arch Dis Child 1987;62:1215-9.

3 Thomas DW, Sinatra FR, Merritt RJ. Random fecal alpha-1-antitrypsin concentration in children with gastrointestian
ology $1981 ; 80: 776-82$.

\section{Monitoring treatment in congenital adrenal hyperplasia}

SIR,-Appan et al are to be congratulated on achieving normal growth in so many of their patients with congenital adrenal hyperplasia. I would not wish paediatricians to conclude, however, that the management of this condition merely requires a standard dose of glucocorticoid and mineralocorticoid calculated from surface area to be chosen at birth and growth monitored thereafter until adulthood. The decision to adjust treatment on the basis of an abnormal change in growth velocity or skeletal maturation is inevitably a retrospective one. The authors concede that an advanced bone age can rarely be recovered. Why not try to predict such an occurrence before it is too late?

The biochemical indices to monitor control are by no means entirely reliable alone. They are certainly useful to detect problems with treatment compliance, particularly plasma testosterone values which are less influenced by good short term compliance. Appan et al conclude their paper by stating that frequent adjustment of medication is needed during periods of rapid growth in infancy and puberty. Periods of short term monitoring of biochemical indices along the lines recently recommended, ${ }^{2}$ together with the use of standard auxological techniques in the longer term, is surely a sensible way to achieve this. I A HUGHES Department of Paediatrics Level 8, Addenbrooke's Hospital, Hills Road, Cambridge CB2 $2 Q Q$

1 Appan S, Hindmarsh PC, Brook CGD. Monitoring treatment in congenital adrenal hyperplasia. Arch Dis Child 1989;64:1235-9. 2 Hughes IA. Management of congenital adrenal hyperplasia. Arch Dis Child 1988;63:1399-404.

\section{Herpes simplex infections in atopic eczema}

SIR,-Patients with atopic eczema have an increased susceptibility to cutaneous viral infections, including herpes simplex, common warts, vaccinia, and molluscum contagiosum This is thought to be due partly to a mild but definite depression of $\mathrm{T}$ cell function. ${ }^{1}$

I was struck, however, by the apparent high incidence of the herpes simplex infection in children admitted to the Birmingham Children's Hospital with an acute exacerbation of atopic eczema. To test my observations, I did a retrospective study to find this incidence in those admitted over a period of two years and a prospective study over a period of one year.

Swabs were taken if herpes simplex was clinically suspected-that is, there were vesicles or pustules in a child with atopic eczema. The presence of the herpes simplex virus was tested by indirect immunofluorescence and cytopathic changes on tissue culture.

During the retrospective two year period 10 out of 119 children were confirmed to have a herpes simplex skin infection. The prospective study, over a period of one year, showed eight out of 74 children with atopic eczema to have a confirmed herpes simplex skin swab. Thus during the combined three year period, the incidence of the virus was approximately $10 \%$. Two children had one recurrence and one child had two recurrences.

All children confirmed to have a herpes simplex skin infection improved after seven to 10 days even though two, initially, had developed severe systemic upset. They were all treated with a five day course of oral acyclovir. Herpes simplex was confirmed in all children who were clinically suspected of having the virus, reflecting the ease of diagnosis and of culture of the virus. The incidence of about $10 \%$ of herpes simplex infection in acutely exacerbated atopic eczema was also found by David and Longson. ${ }^{2}$ This incidence may have been an underestimate as swabs were only taken on clinical suspicion that the virus was present. There may have been similar underestimations in our study. When infected eczema fails to respond to antibiotics within two days this is thought to suggest a herpes simplex infection. ${ }^{2}$ It would be interesting to determine the incidence of the herpes simplex virus in acute eczema when it is not clinically obvious.

This study confirms my observation of the high incidence of herpes simplex in atopic eczema. It should always be considered in an acute exacerbation of atopic eczema as it can cause considerable associated systemic disease.

B J LIDDLE The General Hospital, Steelhouse Lane Birmingham B4 6NH

1 Carapeto FJ, Winkelmann RK, Jordan RT. $T$ and $B$ lymphocytes in contact and atopic dermatitis. Arch Dermatol 1976;112:1095-100.

2 David TJ, Longson M. Herpes simplex infections in atopic eczema. Arch Dis Child 1985; 60:338-43.

\section{Self management plans for asthma}

SIR,-Comics and booklets, training courses for patients, asthma nurses-do they help to reduce morbidity in asthma? The evidence is at worst negative and at best contradictory. A consensus is emerging that self management is the key to good control and that a clearly written set of instructions-a self management plan-is the means to achieve this goal.

The article by Fletcher et al suggests that clear advice might have helped to preven some deaths from asthma. ${ }^{1}$ Two recent articles from Thorax come to similar conclusions.

Sibbald concluded that psychological factors were not major determinants of the responses of her adult asthmatic subjects to two hypothetical attacks of asthma. ${ }^{2}$ Simple messages, teaching patients how to cope rather than trying to improve their knowledge of disease, would be most likely to reduce morbidity. A self management scheme of this type was assessed in an open study by Beasley and colleagues. ${ }^{3}$ A written plan and a peak flow meter were provided for each of the subjects. Patients improved over a seven month period, suggesting that the plan was successful. A controlled study, with an assessment of the (nonstandard) advice given and an analysis of the important features which were responsible for improved control, will be essential sequels to this study.

Of immediate practical help, the National Asthma Campaign has recently introduced two children's asthma cards, based largely on a similar design used successfully at
Hammersmith Hospital for over 10 years. ${ }^{4}$ One card is for personal use by parents or child. The other is to be taken to school. There are sections for regular treatment, relief treatment, and emergency management. Brief guidelines are printed for the emergency doctor and for the parents or school teachers.

The cards are available at no charge from The National Asthma Campaign, 300 Upper Street, London N1 2XX. I urge you to use them.

$$
\begin{array}{r}
\text { M SILVERMAN } \\
\text { Royal Postgraduate Medical School, } \\
\text { Hammersmith Hospital, } \\
\text { London W12 OHS }
\end{array}
$$

1 Fletcher HJ, Ibrahim SA, Speight N. Survey of asthma deaths in the Northern region, 1970-85. Arch Dis Child 1990;65:163-7.

2 Sibbald B. Patient self care in acute asthma. Thorax 1989;44:97-101.

3 Beasley $R$, Cushley $M$, Holgate ST. A self management plan in the treatment of adult management plan in the treatmen
asthma. Thorax $1989 ; 44: 200-4$.

4 Silverman M. Asthma in childhood. London: Current Medical Literature, 1985.

Effect of fever on recurrence rate of febrile convulsions

SIR,--The paper by Drs El-Radhi and Banajeh may be criticised on the grounds that they have combined data from retrospective and prospective studies for joint analysis. ${ }^{1}$ Even if their results were to be accepted at face value, I suspect that they have drawn the wrong conclusion from their data. Rather than suggesting that the height of the initial fever provides stimulation of non-specific immunity, thereby reducing the chance of future infections (are we therefore misguided in trying to lower fever?), it is surely more reasonable to interpret their data by assuming that there is natural variability in the temperature threshold required for convulsion. Any individual may convulse if the temperature rises high enough, as in heat stroke, and as the incidence of febrile convulsion decreases with age, cerebral maturation appears to be associated with increase in temperature threshold required for convulsion. Their groups are clearly self selecting: those infants convulsing with temperatures below $39^{\circ} \mathrm{C}$ have a low temperature threshold and would be expected to have more attacks, as more infections cause pyrexias of $38-39^{\circ} \mathrm{C}$ than $40-41^{\circ} \mathrm{C}$. Those requiring temperatures above $40^{\circ} \mathrm{C}$ will have less, both because high pyrexia is less common, and because their convulsion threshold will increase naturally with age to levels above those caused by infectious illness.

Perhaps we should be directing our attention to those infants who present with convulsion associated with low grade fever. Simple methods of fever control are less likely to prevent a pyrexia of $38.5^{\circ} \mathrm{C}$ than one of $40-41^{\circ} \mathrm{C}$, and it may be appropriate to consider early introduction of anticonvulsant treatment in this group. This could be withdrawn after a relatively short period of six months to one year, as the infant's convulsion threshold may well have risen to levels where fever control alone is adequate.

S MURCH Department of Child Health, West Smithfield, London ECIA $7 B E$

1 El-Radhi AS, Banajeh S. Effect of fever on recurrence rate of febrile convulsions. Arch Dis recurrence rate of febrild $1989 ; 64: 869-70$. 